\title{
About anesthesiology and surgery: analgesia, anaesthesia, and non-surgical papers published in journals of surgery
}

\author{
Marius M. Scarlat ${ }^{1} \cdot$ Andreas F. Mavrogenis $^{2}$
}

Published online: 27 October 2021

(c) The Author(s) under exclusive licence to SICOT aisbl 2021, corrected publication 2021

Subjects treated in a general orthopaedic publication are innumerable. Some themes could not be included in a very specialized journal or in a technical publication because they treat "borderline" subjects such as the biology of healing in tissues, patient-related outcomes in a specific procedure, or pain management. Other papers that have a difficulty in finding a place are participation of vitamins or regimes in healing, education in preparation of patients for a specialized procedure such as joint replacement, and doctor's experience in introducing new procedures.

We published many such controversial subjects related to orthopaedics and conjunctive tissue [1-3]. We published papers dealing with the use of specific molecules like tranexamic acid during surgery [4-7]. We published also papers related to the use of drugs or medications before or after surgery as well as regional anaesthetic blocks [8-11]. However, the most read and cited borderline papers are dedicated to pain management and blood loss as well as the outcome studies in controversial subjects [12-15].

Some of the published papers were dedicated to analgesia and anaesthesia. For millennia, pain was a major subject for both patients and doctors and modern anaesthesia realized unbelievable progress in managing pre-operative and postoperative care as well as the realization of surgery "per se" $[16,17]$. No surgery without anaesthesia. The surgical team includes as pre-requisite the presence of a specialized anesthesiologist doctor or assistant. Difficult cases are managed correctly with pre-operative and post-operative protocols. Many patients are old, presenting comorbidities and chronic treatments such as anticoagulants or respiratory medication. Patients become more and more demanding and the cases become more complex and difficult. Is it reasonable to refuse

Marius M. Scarlat

mscarlat@gmail.com

1 Groupe ELSAN, Clinique St. Michel, Toulon, France

2 First Department of Orthopaedics, National and Kapodistrian University of Athens, Athens, Greece anaesthesia for a patient that is otherwise walking on the street, living with family, have $98 \%$ oxygen saturation, just because he or she is fat? There are obviously some perfect anesthesiologists who are obsessed with regime or body fat and reject obese patients. By the time of Rubens, fat people were considered healthy and prosperous, now we have the "Instagram doctor" who would like to set up new standards in well-being pushing youngsters to remodel their bodies up to an A4 paper width and perform 40 minutes of cardio per day. Vegetarians, vegans, bodybuilders, anorexics, drug addicts, depressed, chronic respiratory disease patients, Mister Pickwick, chronic hepatic suffering individuals, transplanted people, and so many more, they are all our patients. They are in need for chronic treatment and sometimes they are also in need for a knee replacement, hip surgery, or arthroscopy for fixing a terribly painful shoulder or a broken ankle. Old, isolated, dependant, alone people without families who enjoy being in the hospital for the holidays, they all come to see the surgeon and the anesthesiologist. We try to understand them all and evaluate their motivations for asking medical attention.

Anesthesiologists calculate scores and evaluate patients in pre-operative clinics. Usually they accept to take the individual, assuming that whatever happens and whatever risk we take, they are ready to follow until discharge, until the patients could eventually walk on their own feet and go home or in a convalescence facility. However, very few anesthesiologists follow the patient's outcomes in long term. Studies related to outcomes after difficult surgery with anesthesiological challenges are still performed by the surgeons who do the post-operative follow-up. Patients with hypoalbuminemia, anaemia, and poor neurologic conditions are seen by the surgeons who evaluate outcomes. Papers related to anesthesiological challenges are also written by surgeons who do the follow-up evaluation [18].

If a patient performs poorly after surgery, it is usually the surgeon's responsibility to manage complications: phlebitis, oedema, superficial and deep infections, nerve impairment, 
gait and difficulties to integrate home, allergic conditions secondary to the wound dressing or medication. Once the patient is out of the operating room or from the hospital, the only responding individual is the surgeon or the surgeon's team. However, a good anesthesiologist will be able to manage, prevent, and cure in a preventive manner the threatening conditions before and during surgery and the hospital stay. Ideally, their work does not stop immediately as the patient is out of the recovery room.

As John Steinbeck wrote in the late 1930s, being empathic and compassionate is the key for success. "Try to understand men, if you understand each other you will be kind to each other. Knowing a man well never leads to hate and nearly always leads to love. There are shorter means, many of them. There is writing promoting social change, writing punishing injustice, writing in celebration of heroism, but always that base theme. Try to understand each other." This is why we try to understand all human and medical motivations pushing anesthesiologists to work, evaluate, and perform so well, saving lives and improving patient's well-being worldwide. The quality of their work and dedication is a part of our mutual success for better results with surgery and alternative methods of treatment. Publishing anesthesiology papers in orthopaedic endeavors is a matter of honor for the team we are. For the anesthesiologists who care for us and for our patients. This editorial is dedicated to them.

\section{Declarations}

Conflict of interest The authors declare no competing interests.

\section{References}

1. Gilat R, Haunschild ED, Knapik DM, Evuarherhe A Jr, Parvaresh KC, Cole BJ (2021) Hyaluronic acid and platelet-rich plasma for the management of knee osteoarthritis. Int Orthop 45(2):345-354. https://doi.org/10.1007/s00264-020-04801-9

2. Sun JN, Chen W, Zhang Y, Zhang Y, Feng S, Chen XY (2020) Does cognitive behavioral education reduce pain and improve joint function in patients after total knee arthroplasty? A randomized controlled trial. Int Orthop 44(10):2027-2035. https://doi.org/10.1007/ s00264-020-04767-8

3. Gądek A, Liszka H, Zając M (2021) The effect of pre-operative high doses of methylprednisolone on pain management and convalescence after total hip replacement in elderly: a double-blind randomized study. Int Orthop 45(4):857-863. https://doi.org/10.1007/ s00264-020-04802-8

4. Palija S, Bijeljac S, Manojlovic S, Jovicic Z, Jovanovic M, Cvijic P, Dragicevic-Cvjetkovic D (2021) Effectiveness of different doses and routes of administration of tranexamic acid for total hip replacement. Int Orthop 45(4):865-870. https://doi.org/10.1007/ s00264-020-04585-y

5. Shodipo OM, Jatto HI, Ramat AM, Ibrahim SS, Ajiboye LO, Arojuraye SA, James JA, Toluse AM (2021) Comparison of single versus double tranexamic acid dose regimens in reducing post-operative blood loss following intramedullary nailing of femoral fracture nonunions. Int Orthop. https://doi.org/10.1007/s00264-021-05220-0
6. Changjun C, Xin Z, Yue L, Chengcheng Z, Qiuru W, Qianhao L, Pengde K (2021) Tranexamic acid attenuates early post-operative systemic inflammatory response and nutritional loss and avoids reduction of fibrinogen in total hip arthroplasty within an enhanced recovery after surgery pathway. Int Orthop. https://doi.org/10.1007/ s00264-021-05182-3

7. Poonam Pai BH, Diskina D, Lin HM, Vulcano E, Lai YH (2021) Use of tranexamic acid does not influence perioperative outcomes in ambulatory foot and ankle surgery-a prospective triple blinded randomized controlled trial. Int Orthop 45(9):2277-2284. https:// doi.org/10.1007/s00264-021-05131-0

8. Wang Q, Sun J, Hu Y, Zeng Y, Hu J, Yang J, Kang P (2020) Effects of morphine on peri-articular infiltration analgesia in total knee arthroplasty: a prospective, double-blind, randomized controlled trial. Int Orthop 44(12):2587-2595. https://doi.org/10.1007/ s00264-020-04700-z

9. Hernigou J, Labadens A, Ghistelinck B, Bui Quoc E, Maes R, Bhogal H, Callewier A, Bath O, Chahidi E, Safar A (2021) Vitamin $C$ prevention of complex regional pain syndrome after foot and ankle surgery: a prospective randomized study of three hundred and twenty nine patients. Int Orthop 45(9):2453-2459. https://doi.org/ 10.1007/s00264-021-05159-2

10. Li D, Alqwbani M, Wang Q, Yang Z, Liao R, Kang P (2021) Ultrasound-guided adductor canal block combined with lateral femoral cutaneous nerve block for post-operative analgesia following total knee arthroplasty: a prospective, double-blind, randomized controlled study. Int Orthop 45(6):1421-1429. https://doi.org/10.1007/ s00264-020-04549-2

11. Choi S, Kim T, Kwon YS, Kang H (2019) Intra-operative effect of interscalene brachial plexus block to arthroscopic rotator cuff repair surgery. Int Orthop 43(9):2117-2124. https://doi.org/10.1007/ s00264-018-4199-x

12. Tarasov DA, Lychagin AV, Yavorovkiy AG, Lipina MM, Tarasova IA (2020) C-reactive protein as marker of post-operative analgesic quality after primary total knee arthroplasty. Int Orthop 44(9):17271735. https://doi.org/10.1007/s00264-020-04551-8

13. Schubert MF, Thomas JR, Yashar J, Lee JJ, Urquhart AG, Gagnier JJ, Pour AE (2020) Post-operative urinary retention after lower extremity arthroplasty and the peri-operative role of selective alpha- 1 adrenergic blocking agents in adult male patients: a propensity-matched retrospective cohort study. Int Orthop 44(1):39-44. https://doi.org/10.1007/s00264-019-04420-z

14. Sadoun M, Hardy A, Cladière V, Guichard L, Bauer T, Stiglitz Y (2021) Outpatient total ankle replacement. Int Orthop 45(9):2429 2433. https://doi.org/10.1007/s00264-021-05140-z

15. Cohen-Levy WB, Rush AJ 3rd, Goldstein JP, Sheu JI, HernandezIrizarry RC, Quinnan SM (2020) Tranexamic acid with a preoperative suspension of anticoagulation decreases operative time and blood transfusion in the treatment of pelvic and acetabulum fractures. Int Orthop 44(9):1815-1822. https://doi.org/10.1007/ s00264-020-04595-w

16. Mavrogenis AF, Saranteas T, Markatos K, Kotsiou A, Tesseromatis C (2019) Pharmacies for pain and trauma in ancient Greece. Int Orthop 43(6):1529-1536. https://doi.org/10.1007/ s00264-018-4219-x

17. Markatos K, Karamanou M, Saranteas T, Mavrogenis AF (2019) Hallmarks of amputation surgery. Int Orthop 43(2):493-499. https:// doi.org/10.1007/s00264-018-4024-6

18. Hakim J, Volpin G, Amashah M, Alkeesh F, Khamaisy S, Cohen M, Ownallah J (2020) Long-term outcome of total knee arthroplasty in patients with morbid obesity. Int Orthop 44(1):95-104. https://doi. org/10.1007/s00264-019-04378-y

Publisher's note Springer Nature remains neutral with regard to jurisdictional claims in published maps and institutional affiliations. 